\title{
AN EARLY MANUSCRIPT IN THE HISTORY OF AMERICAN COMPARATIVE PSYCHOLOGY: Lewis Henry Morgan's "Animal Psychology" (1857)
}

\author{
By: Timothy D. Johnston*
}

Dohnston, T. D. 2002. An early manuscript in the history of American comparative psychology: Lewis Henry Morgan’s “Animal Psychology” (1857). History of Psychology, 5:323-355.

Made available courtesy of the American Psychological Association:

http://www.apa.org/journals/hop

\section{This article may not exactly replicate the final version published in the APA journal. It is not the copy of record.}

\begin{abstract}
:
Lewis Henry Morgan (1818-1881) is best known as the 1st ethnographer of Native American culture, but he also wrote on animal psychology, beginning in 1843, some 50 years before the founding of comparative psychology as a scientific discipline. Although not an evolutionist, Morgan argued that animals possess many human mental abilities, such as reason and moral judgment, and he rejected the scientific utility of the concept of instinct, a view that did not gain much currency in psychology until the rise of behaviorism in the 1920s. This 1857 manuscript, which is in the Lewis Henry Morgan Papers at the University of Rochester in Rochester, New York, formed the basis for the last chapter of his 1868 monograph on the American beaver but gives additional information on his sources and an expanded criticism of the concept of instinct.
\end{abstract}

*Timothy D. Johnston is a biologically trained psychologist with interests in the roles of experience and gene activity in behavioral development, the relation between developmental and evolutionary change in behavior, and the history of efforts to understand both of those scientific

problems.

Lewis Henry Morgan's manuscript collection is the property of the Rush Rhees Library, University of Rochester, and this manuscript is published here with their permission. I am most grateful to Nancy Martin, of the Department of Rare Books and Special Collections, for making the manuscript available, and for her kind assistance in many ways throughout the project. Melissa Mead supplied the photographs and provided Web space for a transcription of Morgan's manuscript. Several colleagues at the University of North Carolina at Greensboro also provided invaluable assistance. Nancy Fogarty and Gaylor Callahan of the Jackson Library staff helped to identify and locate several of Morgan's more obscure references. Susan Shelmerdine and Linda Danford, of the Department of Classical Studies, translated Morgan's Greek and Latin (respectively) and helped identify his classical references. Preparation of this article was made possible in part by a research assignment from the University of North Carolina at Greensboro for the fall 2001 semester.

Correspondence concerning this article should be addressed to Timothy D. Johnston, Department of Psychology, University of North Carolina at Greensboro, P.O. Box 26170, Greensboro, North Carolina 27402-6170. E-mail: johnston@uncg.edu 
Article:

The scientific study of comparative psychology in America began in the late 1890s as a result of the application of experimental methods learned in German laboratories to questions about animal learning and other mental abilities raised by British evolutionary naturalists. The American scientists generally identified as the first comparative psychologists include Willard S. Small (1870-1943), Linus Kline (1866-?), and Edward L. Thorndike (1874-1949), ${ }^{1}$ all of whom began their careers in the decade after the publication of James's Principles of Psychology. ${ }^{2}$ However, an extensive if scattered body of literature on many topics that are central to the definition of comparative psychology was published by U.S. authors between 1843 and $1890,{ }^{3}$ although this work never coalesced into a coherent "research programme" ${ }^{4}$ as did that of later psychologists around the turn of the century. One early American writer on such topics was Lewis Henry Morgan (1818-1881), a pioneering student of Native American ethnography and one of the founders of evolutionary anthropology. ${ }^{5}$ The manuscript published here, which is housed in the Lewis Henry Morgan Papers at the University of Rochester in Rochester, New York, is one of the earliest writings by an American author dealing with a variety of issues that would later be of central importance to the field of comparative psychology.

Morgan was born near Aurora, New York, studied law at Union College in Schenectady, and started a law practice in Rochester in 1844. Early in his career, he became interested in Iroquois culture and traditions and in 1851 published The League of the Ho-de-no-sau-nee, or Iroquois, ${ }^{6}$ the first ethnographic account of indigenous American culture. In addition to his well-known work in anthropology, Morgan was interested in the nature of the animal mind and its relationship to the human mind. In one of his first published papers, ' he undertook a critical analysis of the concept of instinct, concluding that it is not helpful for understanding the behavior of nonhuman animals, or mutes, as he called them. Morgan thought that although "the Mutae" lack the power of speech, in other respects their mental abilities are similar in kind to those of humans. Morgan was not an evolutionist: He believed in divine creation and the fixity of species, although he allowed for the existence of certain kinds of gradual change. In particular, he believed that human society has undergone change throughout history, passing through a number of distinct stages, from an initial state of savagery to the final stage of modern civilization, a position that led later writers to describe him as an evolutionary anthropologist. ${ }^{8}$ He was not, however, an evolutionary thinker in the modern sense of the word.

In all of his writings on animal psychology, Morgan maintained a consistent view of the common practice of attributing animal behavior to instinct: He thought it demeaned animals, was inconsistent with the evidence about their behavior, and impeded our understanding of their mental abilities. In the term instinct, he wrote, we have "a system of philosophy in a deffinition; we have an installation of the supernatural, which silences at once all inquiry into the facts" (manuscript [MS] p. 1). In his rejection of instinct on the grounds of conceptual inadequacy, Morgan anticipated some ideas of later contributors to the "anti-instinct" movement of the early 20th century, such as Knight Dunlap and Zing-Yang Kuo, ${ }^{9}$ who made similar arguments, although as behaviorists neither of them entertained the idea of animal reason. Dunlap accepted the existence of a limited class of instinctive behavior but argued that the concept was far too broadly and vaguely applied to be 
analytically useful. Kuo was more radical, especially in his later writings, eventually maintaining that the concept has no applicability to behavior at all. Morgan, it seems, wanted to reject the concept outright (like Kuo), although in places he softened his criticism to allow that it might apply to some limited class of both human and animal behavior. ${ }^{10}$

Like other 19th-century writers (including Darwin), Morgan's ideas about animal behavior were based on a combination of anecdotal evidence and some first-hand observations - in Morgan's case, primarily on the American beaver. Although some of the anecdotes seem quite farfetched, they are not especially so, given the evidentiary standards of the time, which seem rather weak in comparison with those of today. Morgan's view of the relationships between humans and nonhuman animals is interesting. He referred to a "scale of gradation" along which living species can be arranged, with man at the top. However, he also argued that mental abilities may be developed to different degrees in different species, that humans are not superior to animals in every mental respect, although humans have an overall mental advantage. He speculated that the gap between the least wellendowed humans and the most well-endowed animals "is sufficiently great to suggest, at least, the idea, that some intermediate species, and perhaps several of them, have dropped out in the course of the early ages, or that some existing species have been degraded beyond redemption" (MS p. 22). This quasievolutionary suggestion, however, did not lead him to accept Darwinian evolutionary thinking, which is nowhere to be found in his writings. Morgan believed firmly in divine creation and in the special standing accorded to the human species, but he considered the differences between humans and other animals to be a matter of degree, not of kind, and even went so far to attribute (cautiously) a moral sense and an immortal soul to the Mutes that so engaged his attention.

\section{PICTURE IS OMITTED FROM THIS FORMATTED DOCUMENT}

Morgan was not, of course, the only 19th-century writer to maintain that animals can reason, make decisions, and carry out other mental activities traditionally reserved to humans. George Romanes, in particular, willingly attributed these "higher mental powers" to nonhuman animals and has been criticized by generations of psychologists (beginning with C. Lloyd Morgan) for his attributions. ${ }^{11}$ What makes Lewis Morgan especially interesting is that he denied any significant role for instinct in complex animal behavior and even denied that the concept has any scientific utility, a position that sets him apart from virtually all writers on animal behavior until the 1920 s. $^{12}$

This manuscript is titled "Animal Psychology" and is annotated at the top right of the first page with the words "Read before 'The Club' Apr. 7, 1857." Morgan organized and participated in several fraternal discussion groups during his life, and "The Club" refers to the Pundit Club, which was established in Rochester, New York, in the summer of 1854 with Morgan as secretary. ${ }^{13}$ It was evidently written after the first of Morgan's trips to the Midwest in 1855 (made in connection with his investments in a railroad company) during which he spent time studying the constructions of beavers in the Upper Peninsula of Michigan and gathering information about their habits. Morgan traveled to Marquette, on the south shore of Lake Superior, almost every summer between 1855 and 1867, and recorded his first observations and sketches of beaver dams and lodges in his notebook on August 24, 1860. ${ }^{14}$ These observations formed the basis for The American Beaver and His Works (1868), one of the earliest zoological monographs on a single species, which provides a detailed account of beaver behavior and ecology, with a particular focus on dams, ponds, canals, and other examples of construction. ${ }^{15}$ 
Morgan had used the beaver to provide examples of animal intelligence in his 1843 article on instinct, ${ }^{16}$ and he seems to have been especially interested in the animal even before his midwestern trips. The time he spent observing beavers in the wild undoubtedly added to his understanding of their behavior, however, and deepened his conviction that complex animal behavior should be attributed to reason, not to instinct.

The manuscript published here formed the basis for the last chapter of Morgan's book, which is also titled Animal Psychology.'? The organization is similar, many of the examples are the same, and several descriptions of animal behavior quoted or alluded to in the manuscript are repeated, often verbatim, in the book. In both, Morgan begins with a denunciation of the use of the term instinct to explain animal behavior (more vigorous in this manuscript than in the later chapter) and then proceeds to defend his, position on both theoretical and empirical grounds. The six propositions that outline Morgan's conclusions on MS p. 3 are omitted from the published chapter, and the three main sections into which the MS is divided (I. Analogy of Structure; II. Memory; and III. Perception, Reflection, and Volition) are rearranged and expanded into eight sections that use published and unpublished descriptions and anecdotes of animal behavior, as well as Morgan's own work on beavers, to argue for his position. The closing pages of both the manuscript and the chapter make three concluding points: (a) that living species can be arranged in a gradation of mental ability, with the human species at the head; (b) that humans may not be the only species to show progressive improvements in ability from one generation to the next; and (c) that humans' treatment of other animals (which Morgan thought deplorable) would be improved if humans recognized their mental similarities to animals: "If we recognize the fact that the mutes possess a thinking, and reasoning, and perhaps an immortal principle, our relations to them will appear to us in a different, and a better light." ${ }^{18}$ The second of these three points, progressive improvement, later came to play a central role in Morgan's analysis of human societies and is the core of his "evolutionary" anthropology. ${ }^{19}$ The supplemental material that appears on MS pages 27-31 is not included in the chapter, although references to some of the philosophers whose views Morgan discussed in this section (principally Thomas Reid and Sir William Hamilton) do occur.

\section{The Transcription}

In accordance with the terms of the will he drew up in 1878, Morgan's papers were transferred to the University of Rochester after the death of his son Lemuel in $1905 .^{20}$ This manuscript is housed in the Department of Rare Books and Special Collections of the Rush Rhees Library at the University of Rochester (Box 22, Folder 41). It is written in ink, with some pencil insertions, on 34 sheets of 8.5 in. X 14 in. $(21.6 \mathrm{~cm} \mathrm{X} 35.6 \mathrm{~cm})$ lined paper; there are actually 35 pages of writing, because Morgan used the back of one page (p. 181/2) as well as the front. In the transcription published here, the end of each manuscript page is indicated by inserting the page number in brackets, thus: [p. 11. Some pages were apparently added, or at least numbered, after the manuscript was written, and Morgan gave these pages fractional numbers (e.g., 111/2, 113/4); I have used the numbers written by Morgan on each page to indicate pagination. Numbered endnotes are my additions and identify Morgan's bibliographic sources and names he mentions in the text. Because Morgan wrote this manuscript for an oral presentation rather than for publication, many citations were obviously intended only to remind him of a source that he probably knew well, and some are so incomplete or ambiguous that they cannot be identified with certainty. Where a book in Morgan's library has been cited, I have included Trautmann and 
Kabelac's catalog number (see note 20). Most of Morgan's marginal additions to the manuscript have also been included as endnotes, but a few one-word additions, probably intended only as reminders for his presentation, have been omitted. Morgan himself added only one footnote, at the bottom of MS page 4, which is indicated with an asterisk. For ease of reading, I have omitted Morgan's deletions and have indicated substantive insertions by placing them within braces, thus: \{ insertion \}; I have not indicated insertions that involve only minor stylistic or grammatical changes (for example, the word which crossed out and that inserted), or changes in wording that do not materially affect meaning. Variant spellings have been left as they were written, but a few minor corrections to punctuation have been made for clarity. A verbatim transcript of the manuscript, showing all deletions and insertions, and omitting my editorial notes, is available at http://www.lib.rochester.edu/rbk/MORGLH.stm (see Figure 1).

Read before "The Club" Apr. 7, 1857

\section{PICTURE IS OMITTED FROM THIS FORMATTED DOCUMENT}

\section{Animal Psychology}

The endowments of animals have, in all ages of the world, excited discussion; but this discussion has neither inaugurated a science, nor offered any exposition of the intellectual life of the lower orders of animals, in the least degree satisfactory. There are difficulties however; one of which, and a very serious one, is the want of a sufficient knowledge of their habits; another may be found in the abysmal nature of all intellectual science; but a greater than either arises from that stupendous blunder as well as fraud upon the animal races, the introduction of the term "instinct." We have here a system of philosophy in a deffinition [sic]; we have an installation of the supernatural, which silences at once all inquiry into the facts. If it be true that the acts of animals are the result of an inward persuasion, or a spontaneous impulse beyond their control; or the act of an agent which performs ignorantly and blindly a work of intelligence and knowledge then the term instinct will answer all the ends it was designed to subserve; ${ }^{21}$ but on the contrary if these acts are the direct result of perception, reflection and volition, then the deffinition is absurd, and the subject is open like any other to inquiry into the facts.

It would seem to require no argument to prove, that all animals are endowed with a principle which performs the same office in governing their conduct, that the human mind does in regulating the conduct of man \{yet instinctists must deny this . But we shall only venture to assume that man is endowed with a \{certain $\}$ principle, which is distinct from the body, to which all of his acts are referable as a cause or motive power, except such as are strictly $\}$ involuntary. We shall also assume that all animals below man are endowed with a certain principle, which is distinct from the body, to which their acts are referable as a cause or motive power, except such as are strictly involuntary. [p. 1] Of the essence or ultimate nature of this principle we know nothing; neither do we know any thing of the ultimate nature of mind; but we do know that the human mind manifests certain powers as memory, certain passions as anger, certain appetites as hunger, and the true question is, \{first $\}$ whether the corresponding principle in animals manifests certain powers as memory, certain passions as anger, and certain appetites as hunger; and if it does, $\{$ secondly $\}$ whether these powers, appetites and passions in the abstract and the concrete, in particulars and in general, ${ }^{22}$ are essentially similar manifestations; and if differences are detected, are they of kind or only of degree? 
It is complacently said that the Mutae have the appetites and passions in common with man, but that the moral and intellectual endowments of the latter separate him by a broad distinction from the residue of the animal kingdom. This is true as a general proposition, for the difference in degree is immense; but its truth is denied if the distinction is intended to be fundamental. The passion of anger can only be predicated upon a thinking principle, and is a manifestation of that principle as absolutely as memory or imagination. It is an axiom in moral as well as in intellectual science that all pain and pleasure are in the mind, and not in the organs of the body. When therefore we find throughout animated nature that the phenomena of pleasure and pain are \{ everywhere present and $\}$ essentially the same, the universal presence of a thinking conscious principle becomes demonstrated.

Without entering any further into preliminary considerations I shall submit at the outset, in a series of propositions, the conclusions drawn from an examination of this subject. They are the following: [p. 2]

I. That the Mutae are endowed with a principle which performs for them the same office that the human mind does for man.

II.That the attributes and inferentially the ultimate nature of this principle is the same in the Mutae as in man; whether we consider its modes of operation, or those qualities which are common to both, or those differences which distinguish the species.

III.That it is bestowed in different degrees upon the several species in conformity with their structural organization; the endowments of each being admeasured and adapted to the sphere of existence prescribed by their physical powers.

IV. That there is a scale of mind from the human, down to that of the lowest animal; admitting of a diversity of powers but precluding a difference in the substance from which they emenate $[$ sic].

V. That the archetypal animal mind cannot be deduced from the human alone; it embraced the collective endowments of every species; and therefore a full comprehension of this principle involves a consideration of its manifestations throughout the animal kingdom.

VI. That the same arguments from nature which prove the indestructibility of the human mind demonstrate also the indestructibility, and consequent immortality of the endowments of the Mutae. [p. 3]

As it will be impossible in this paper to do much more than touch the skirts of this great subject I shall confine myself to the presentation of a few distinct arguments, and

First,

\section{The Argument From Analogy of Structure}

Zoology has demonstrated that the structural organization of all animals fin each of the four primary divisions $\}^{23}$ is in conformity with one general plan. That some of the features of this plan are developed in every species but the whole of them in none. Out of this diversity of organic forms there arises a series from the lowest and most simple in structure, to the highest and most complex; all united together, not by the chain of successive derivation, but as the parts of one harmonious system of animal life. Thus we are not permitted to lose sight of the fact, that man is a member of the animal kingdom, by the divine favor endowed with the highest 
capacities, and consequently invested [?] with the highest structure; but not thusly loosened from the bond which unites the animal kingdom together.

It is an interesting fact in this connection, that one of the most conspicuous features of this plan, namely the organ of vision, is, with a few exceptions, universally bestowed. From the single moveable eye of the higher animals, to the compound and immovable eye of the insect tribes, the organism $[s i c]$ and functions of the eye are essentially similar.* The location of the eye, the taste [p. 4] the smell, and the auditory apparatus in all animals who possess them, in the immediate vicinity of a brain common to all alike, is another structural fact, bearing testimony to a common plan, and a similar end for which these organisms were designed; namely, that all these animals alike were thusly endowed, and intended to be endowed, with that great and ever marvelous power of perception, which is the primary instrument of all knowledge.

It is by the corporeal senses I exclusively that the thinking principle obtains a knowledge of the external world. They are not only the inlets and the instruments of all objective knowledge, to all the members of the animal kingdom from the greatest to the least; but they are skilfully [sic] adapted to this end and are manifestly created for this purpose. Without some of these senses, the continuance, if not the existance [sic] of animal life would be impossible, for they are a condition of life. That the higher animals are endowed with all the senses is not questioned; nor can we detect the slightest difference between the senses of man, and of the inferior animals, except in the degree of acuteness, and \{in the measure of \} strength. The human race undoubtedly have the most uniform developement [sic] of all the senses as a whole; but the highest perfection of particular senses is to be found among the inferior animals. As these senses, however, are mere vehicles of images, impressions or sensations they \{logically\} presuppose the existence of an intelligent principle to take cognizance of the impressions thus conveyed. Any other induction from the facts would deny and defeat the manifest object for which the senses were created.

It is quite instructive to notice how widely these senses are distributed. In the vertebrata the five senses are uniformly present, except in some few species in which the organ of vision is obliterated. [p. 5] In the Mollusca, the only organs observable are those of touch and sight. In some of the species the latter sense is wanting. Cuvier says that no particular organ of smell has ever been detected in them, although they enjoy this sense (Cuvier, An. King., P. [blank]). ${ }^{24}$ Among the Articulata there is more diversity. Insects have the senses of sight, touch and smell in great perfection. There are some evidences according to Emmons (Nat. Hist. NY Ag. 5, 21) ${ }^{25}$ that they have the sense of hearing; but there are no facts independent of analogy, to prove the existence of the sense of taste. The remaining classes of this division have a less number distinctly manifested. In the Radiata the only sense of which there are certain evidences is that of touch.

\footnotetext{
*Of all the senses that of sight seems to be the most perfect in insects. The organ is compound, or in other words consists of many eyes compacted together, each of which is perfect in itself, being furnished with the proper humors and lenses essential to the exercise of vision ++ Their number is almost incredibly great in some species. They vary in this respect from 50 in the ant, to 25,000 in a species of Mordella. ++ The common house fly has 4000 , the dragon fly 12,554 , the butterfly 17,000 .
}

Nat. Hist. NY, Emmons Agriculture, v. 5, PP. 21, 22. [See note 5.] 
But it is in the vertebrated animals, and especially in the class of mammals, that the analogies of structure are [most) marked and decisive. The nervous system is centralized in a brain, and from thence is distributed throughout the body; the relative position, and functions of the several parts being similar, if not precisely the same in the several species. I doubt not the anatomists could lay out before you the nervous system of a lion, a dog and a man, and could tell you that as a piece of animal mechanism each was constructed on precisely the same principles. That the nerves of sensation and motion, were distributed in the same manner and worked in the same way; that the several ganglia were distributed in the same manner, found in the same connections, and held the same relative position to the brain (and to the nerves of sensation and motion) in each of them. That the differences were precisely such as would adapt each one to the sphere of life prescribed by the law of his structure; differences in combination, but using the same elements and the same principles in each. Again the circulating system is organized not only upon the same general plan, but the organs employed, with some differences in structure, [p. 6] are the same. So also the digestive apparatus, and the organs of respiration. To trace out this conformity of structure into minute details would be quite easy to the anatomists. Modifications of organs would no doubt be found, rendered necessary by the different kinds of food, and the greater or less degree of motions natural to each animal. For example, the organs of respiration, it is well known, are varied among the vertebrata. Birds require the largest quantity of respiration to give to their muscles the strength, and to their bodies the lightness necessary to flight; hence they have not only a double circulation, and an aerial respiration, but they also respire by other cavities besides the lungs. ${ }^{26}$ In most quadrupeds, the quantity of respiration is moderate because they are formed rather to walk, than to run; but in reptiles who are formed to creep or hop, it is lower still; while in fishes it is the least, for the reason that they are suspended in a medium of nearly their own specific gravity, and require but little muscular strength for motion. Now the structure of the higher animals at least, leads decisively to the inference, that each of these organic forms was designed to be actuated and governed by an intelligent principle; a principle not only capable of using the perceptive organs bestowed, but also of making a rational use of the knowledge which these organs were framed to throw perpetually under its cognizance. To deny the existence of the principle is to deny the obvious purpose of this elaborate animal mechanism; it is to close the eyes to an induction both manifest and inevitable. If the existence of the principle, then, is conceded, it must be a thinking reflecting principle; for nothing below it, would make perception of the least utility. If the preceding reasoning be legitimate it follows also that a thinking [p. 7] principle is inseparable from animal life, no matter how low in the scale of structure it may be found.

There is something in the principle of life which transcends all inquiry. A formative power, it builds up the infantile body into maturity and strength, and maintains a perpetual conflict with the elements of decay inherent in the body. Death is not the destruction of this principle, but simply its expulsion from the body by the breaking up of the organism through which it manifested itself. There is not a reason nor a fact which teaches the annihilation of this principle; neither is there a reason or a fact, with which I am acquainted, which demonstrates or can demonstrate that the living and the thinking principles are separate and distinct from each other. "Life is a vortex," according to Cuvier (Cuv. An. King. 14) $)^{27}$ "more or less rapid, more or less complicated, the direction of which is invariable, and which carries along molecules of similar kinds, but into which individual 
molecules are continuously entering, and from which they are continuously departing; so that the form [Cuvier's emphasis] of a living body is more essential to it than its matter. As long as this motion subsists, the body in which this motion takes place is living. When it finally ceases, it dies." So in strict analogy is the life of the mind a vortex, into which images and ideas are continually entering, and from which they are constantly vanishing. (The perpetual flow of the mind suggests the idea of a revolution of some kind; and rather around a shifting center than upon a permanent axis.) $\}$

An argument from analogy standing alone, is rarely conclusive, for induction commences where analogy ceases; but when it is corroborated by similar conclusions drawn from other, and independent premises, it becomes very convincing. Induction roots itself in just such analogies as we have been discussing. [p. 8]

\section{The Argument From Memory}

This faculty has been well termed by some writers the "great organ of the mind," yet the term is used in a figurative sense. As we cannot resolve the intellectual powers into distinct faculties, it will be sufficient to assume that the mind is a something distinct from the body; a principle or essence not divisible into parts, or faculties or organs. "The utmost ingenuity has not been able to advance a step beyond the fact, that the mind remembers, reasons, imagines; and there we must rest contented." [footnote added in pencil: Abercrombie]. ${ }^{28}$

That the great majority of the Mutae remember; and that they do it as really and as absolutely as man, cannot for a moment be doubted. It would insult the intelligence of those before me should I attempt to \{prove this fact, or to \} show that not the slightest difference could be detected between the memory of a man, and of a dog, in a given case. That the evidences of this remembrance were equally quick, equally manifest, and equally absolute. Yet this remembrance, on the part of the inferior animal, cannot be an inward persuasion, or a spontaneous impulse. It must be conceded to be an act of the animal mind, recalling a former perception, treasured in that mind perhaps for years. Its quickness or slowness, its retentiveness or weakness are entirely immaterial. The question is do they remember, and with that great fact established, it will not prove a difficult task to show that the Mutae can dispense with that \{ absurd \} gift, not of the Deity, but of wise and thoughtful man, commonly known as instinct. [instinct is written in a large and heavy hand]

We are not called upon simply to admit that the [p. 9] Mutae remember. We witness that fact daily as a distinct and positive act of the animal mind, leaving no room for doubt or hesitation. But as this memory manifests itself in all respects in the same manner as the memory of the human mind, it must necessarily be referred to a principle distinct from the body, and analogous to the human mind. Memory is one of the qualities by which we establish the existence in man of a principle which we call mind; but we know nothing of its essence. By the same quality the existence of a corresponding principle in the Mutae is proved; but we know no more of its essence. If then we compare the two acts of remembrance, and find them precisely similar in their essential features, the inference that the principles from which they proceeded, were the same (in kind\} would become inevitable. It is true that the thought is perpetually recurring, how vast the difference between a simple memory of familiar objects, or even the remembrance of a series of antecedent facts, and that noble and cultivated memory of the 
human mind, which can not only untreasure the facts of universal knowledge, but also reproduce these processes of reasoning by which the great truths of science and philosophy have been demonstrated. All very true, the difference is immense; but it is a difference in degree, and not in kind. (Sir Wm. Hamilton has given us a definition of memory which is perhaps the best yet furnished, and it defines the memory of a lion as accurately as that of a man. "Memory," he says, "is an immediate knowledge of a present thought involving an absolute belief that this thought represents another act of knowledge that has been (Ham. P.L. 138)." 29

If then we endow a lion with a principle capable of remembering, we give to him a something, which is immaterial, and distinct from the body; and which inevitably is a principle of intelligence. The concession of the power to remember, as it seems to me, carries the main question. The mind, as before remarked, is not a conglomerate of constituent parts; but an essence, not [p. 10] resolvable into parts; therefore the whole mind remembers, and not a particular fraction of it. From its very nature memory is an omnipresent quality in every mental process. It is present in reason, in imagination, in abstraction. Strike out of the mind its power to remember, if such a thing were conceivable, and it would become entirely powerless, if not overthrown. The past utterly lost, the present vanishing with every instant, the future inconceivable for the want of a past, speech impossible, reflection unknown, and the external world a blanc [sic]. But on the other hand give to any created being, in addition to the senses, a principle capable of remembering, and it has at once something more than the power to remember; it has a power to know, and to understand and to reason; in fact an intelligent principle, a thinking power; and this is precisely what we understand the human mind to be. It is a maxim of philosophy "that a plurality of principles is not to be assumed, when the phenomena can possibly be explained by one" (Hamilton, P. L. P. 40). ${ }^{3 \circ}$ The maxim applies with force in the present case. It is only necessary to state it.

The argument from memory grows in strength and decisiveness when we reflect upon the intimate connection between the exercise of this power, and every act of every living creature. Whether we seek for its manifestation in the daily toil of the bee or the ant; in the mechanical skill of the beaver; in the predatory habits and stratagems of the Carnivora; in the watchful and affectionate care of offspring. Whether it ceases with the careful deposite [sic] of the egg as in most of the insect families, or is carried through the period of infancy, as among the higher animals; in the migrations of the feathered tribes; or in the daily [p. 11] round of all animal life in providing for the ever recurring wants of nature. In all these respects, and in others infinitely numerous, the absolute necessity of memory is self evident; and its actual possession is demonstrated by a body of facts altogether final and conclusive.

Now we know of no principle except mind, on which memory can be predicated; and we have no facts on which to assume the existence of two principles, one of which remembers, and one of which reasons. The mind is a unit, and the same course of argument which proves that a principle capable of reason or judgement is mind, must also be used to prove that the principle which remembers is mind. If this be logical, then it follows, that the thinking principle is the same throughout the realm of animated nature; (but yet it may be) bestowed in different degrees in conformity with the structural organization of the several species; the structure of the animal 
determining his sphere of existence. And the difference between the endowments of the several species is not radical ${ }^{; 31}$ it is one of degree, and not of kind. ${ }^{32}$

It is precisely here, as it seems to me, that God has revealed to us a feature in the plan of creation scarcely less wonderful, than the creation of mind itself. That he has called into being one thinking rational principle, and given to it a multiform developement [sic]. ${ }^{33}$ That he has bestowed it upon a series of organic forms, each standing in a (different) relative position to the others, and also in different relative positions to time and to matter. The mind of the Deity sees alike the movement of the atom upon the atom, and the movements and mutual relations of the universe of matter. Man, who stands at the head of the animal series, is about as far removed from the [p. 111/2] zero of matter, the ultimate atom, as he is from the totality of matter, or the Universe; and the subject of knowledge as well as the means of enjoyment below the ken of his rougher intellect and coarser senses which may be open to the more delicate perceptions, and exquisite senses of the tiny insect, may for ought [sic] we know, or have reason to disbelieve, be as great and wonderful, as the subjects of knowledge, and means of enjoyment which fall within man[']s sphere. As time is purely a relative term, it has doubtless an expansion as we descend the scale, which furnishes in itself an increased means of knowledge. A range for the developement [sic] and exercise of the thinking principle is thus laid open; which the different species were created to occupy. Thus the field of knowledge of the thinking principle is vastly expanded by a diversity of organic forms, through which it is constituted to manifest itself; and the sum of the powers of all the species is far greater, than those of any single one. It would seem, then, that a full comprehension of the powers and capacities of the thinking principle necessarily involves a consideration of its manifestations throughout the animal kingdom; for the sum of the capabilities of this principle are not possessed by any species, but dwell in the animal races as a totality, recognizing the lost, as well as existing species, and rendering possible intelligences higher than man endowed with the same principle. This view of the subject tends rather to exalt than debase our estimate of that intellectual and immortal gift of God, which furnishes, in itself, a higher evidence of his power and wisdom, than the Universe of matter, and the laws imposed upon it at the moment of creation. [p. 113/4]

\section{Perception, Reflection, and Volition}

We now come to consider whether the Mutae are capable of these three distinct acts, either one of which is characteristic of an intellectual principle. Upon the question of perception there can be no doubt, and I shall assume that they perceive external objects through the senses, in the same manner, and with the same effect as man does; and that all the phenomena of sensation in perception are the same in both. Not that it will be contended for a moment that the powers of perception in the inferior animals are equal with those of the human race; for as the members of the human family differ widely in the extent and accuracy of their perceptive powers, so is the difference great between the several species of animals. The perception of a simple object, as a tree, is precisely the same in all animals possessed of the organs of vision. If an eye be directed towards it, an impression is made upon the retina, which having been communicated by the optic nerve to the brain, the mind perceives the object. Up to this point the mode of communication with the external world is the same with all animals; but here there is a dividing off. It is denied by those who believe in instinct, that any creature below man, can make a rational use of the perceptions, which it is clear enough he gains every waking moment of his life. But as his acts are found in innumerable instances to be acts of intelligence and knowledge, 
and that he does precisely as a man would under similar circumstances, then to escape the very obvious conclusion that the animal was endowed with a thinking principle, we find the term instinct introduced, ascribing all these acts to a spontaneous impulse, thus denying to every creature below man the power of volition as well as of reflection). [p. 12] And here let me ask your attention I again to this word instinct, that we may see whether any thing can be made of it. The old definitions are both clumsy and absurd. But Sir William Hamilton has given us one of a human instinct, which seems to me to express precisely what is intended by the term instinct as applied to animals. He says, "an instinct is an agent which performs blindly and ignorantly a work of intelligence and knowledge" (Hamilton PL, P. 62). ${ }^{34}$ This agent is necessarily a spiritual, and not a material one. It must then $\}$ be the work of the mind, or of some other principle connected with the body, and which it is, the definition is not particular to inform us. If I have been able to reach the authorns meaning, it is this. First that the mind is percipient of itself, and is necessarily conscious of all of its own processes. ${ }^{35}$ Now there are some acts performed by man perfectly intelligent and sensible, which he cannot tell how he came to perform. He was conscious of no anterior process of reasoning \{ which led to the act $\}$, therefore it was not the deliberate act of his mind. Ergo it was the act of an unknown agent which possessed the power blindly and ignorantly to perform a work of intelligence and knowledge. This deffinition [sic] of instinct can $\{$ not $\}$ bear examination any better than the old ones. The mistake lies in assuming that the mind is necessarily conscious of all of its own processes, and that it is at all times percipient of itself. The mind is capable of operating with electrical rapidity. We teach the mind to think in human language, to cloth[e] its thoughts in a dress of words. These words are material so to speak, and the use of every syllable requires a particle of time. Hence our mental processes which are deliberate require time for their evolution. But once place the mind under the pressure of excitement, or sudden peril, and away in an instant goes your cumbrous machinery of human words; and the mind flies along a line of images for shorthand symbols, all perfectly intelligible hieroglyphics, ${ }^{36}$ at a rate of velocity which defies [p. 13] the tardy speed of consciousness. It is reasonable to believe that all those acts of ours which we cannot account for in any rational manner, are the work, in some way we cannot fully understand, of that great and marvelous endowment, the thinking principle. For that class of phenomena of the human mind usually called instinctive we have a corresponding class of phenomena among the inferior animals, but beyond these the acts of the Mutae are as explainable as those of the human race. The newborn infant nurses, as they say instinctively. But the fact that it nurses is not more certain than that a human soul ${ }^{37}$ dwells in that infantile body. When any act manifests intelligence I should be very slow to believe the act either automatic or supernatural. It is far more reasonable, and in accordance with what we know of the principle of intelligence P8 to believe that the infantile mind was capable of experiencing the pain of hunger, and of knowing by intuition how to appease it, than to suppose this act to be the result either of physical machinery or supernatural power.

Whether the Mutae reflect or reason can only be demonstrated by their acts. We cannot settle that point by the question direct. Under this branch of the subject some examples will be presented. The Rev. J. Murray in his work on Creation ${ }^{39}$ tells the following story. "An old and respectable man in the county of Montgomery used frequently to relate a circumstance he saw. In his youth he resided on the banks of the Hudson. One day he went to a bay on the river to shoot ducks or wild geese. When he came to the river he saw six geese beyond shot. $\mathrm{He}$ determined to wait for them to approach the shore. While sitting there he saw a fox come down 
to the shore, and stand some time and observe the geese. At length he turned and went into the woods [p. 14] and came out with a very large bunch of moss in his mouth. He then entered the water very silently, sank himself, and then keeping the moss above water, himself concealed, he floated among the geese. Suddenly one of them was drawn under water, and the fox soon appeared on the shore with the goose on his back. He ascended the bank and found a hole made by the tearing up of a tree. This hole he cleared, placed in the goose and covered it with great care, strewing leaves over it. The fox then left; and while he was gone, the hunter unburied the goose, closed the hole and resolved to wait the issue. In about half an hour the fox returned with another in company. They went directly to the place where the goose had been buried, and threw out the earth. The goose could not be found. They stood regarding each other for some time, when suddenly the second fox attacked the other most furiously, as if offended by the trick of his friend. During the battle he shot them both."

Dr. Burrows in his lecture in Albany cited an instance related by Dr. Abell in which a Newfoundland dog exhibited a dignified self esteem. ${ }^{40}$ He had been $\{$ much $\}$ annoyed by a diminutive cur, who with a safe distance between them ran after him whenever he passed. Finally the stately brute seized upon the little scrub by the nape of the neck, carried him howling to the river, into which he deliberately dropped him, and after standing for a while watching his struggles, he plunged in after him, and brought him safely to shore cured of his ambition. If he had torn his ears for him it would have been according to what we understand of the instinct of a dog; but was not this procedure something more than instinct?

There is one branch of the inquiry upon which all the time we are now able to give to this subject might be well expended; and that is \{upon\} [p. 15] the acts of the inferior animals offensive in taking their prey, defensive in providing for their safety and strategical, both for offensive and \{defensive purposes. Who ever looked into the great, round clear eye of a lion without being impressed with the belief that there was a powerful will behind it; and a quick intelligence which on the open plain or in the jungle it would be hard to deceive, and difficult to overmatch. The life of every animal is made to him the price of vigilance; for every species wars and preys upon nearly every other, first the carnivorous upon the non-carnivorous for the means of life; then the carnivora war with each other; and lastly, man treats them all alike as without any rights whatever (even to life itself) except by his permission; which one fact is no slight evidence that man is still a barbarian and a savage. This state of mutual relation in the animal kingdom not only renders the possession of intelligence absolutely necessary to every species for self preservation; but it has thrown in upon us a flood of evidence that they do reason, and reason acutely. The fox, for example, when pursued runs in the bed of some shallow creek to conceal every trace of his scent and footprints; or runs back upon his own track for some distance, and then makes a long leap at right angles, to breake [sic] the chain by which he is followed, and thus to puzzle his pursuers. He evidently understands the means by which he is followed, namely his scent, or foot prints, and devises these plans to render them useless. \{Deer the same. He has also been known to feign death, under circumstances indicating a presence of mind somewhat extraordinary. A farmer once told me that a fox entered his hen house one night through a small apperture [sic], which was the only opening, and succeeded without disturbing the family in destroying a sufficient number of the fowls to gorge himself; whereby [p. 16] he so enlarge[d] his dimensions as to render his egress through the opening impossible. In the morning the farmer discovered the havoc of the night, and the fox himself sprawled out on the floor of the coop 
apparently dead from surfeit. He entered, and taking the creature by the heels, carried him out, and across a little green sward to the side of the house, where he threw him down. This was no sooner done than the fox bounded up and away at full speed. ${ }^{41}$

This trait is not peculiar to the fox. DeKay ${ }^{42}$ (Nat. Hist. NY, Part 1, Zool. Page 4), thus speakes [sic] of the opossum. "He appears to depend more upon cunning than upon strength or activity for the means of escape. When surprised on the ground he compresses himself into the smallest possible space, and remains perfectly quiet. If discovered and even handled in this state, it still counterfeits death, and takes the first opportunity to effect its escape. From this, and other traits of cunning has arisen the local phrase of "playing possum" to designate any adroit cheat."

$\{\text { Read here the story of Herndon[']s tiger. Valley of the Amazon, 312. }\}^{43}$

Dr. Kane (Arctic Explo. V 1, P. 149) ${ }^{44}$ has immortalized Grim, \{ one of $\}$ his Newfoundland $\operatorname{dog}[\mathrm{s}]$ firstly by introducing his intelligent face into his book, and secondly by telling the following story of him. "Grim" he says, "was an ancient dog; his teeth indicated many winters, and his limbs, once splendid tractors for the sledge, were now covered with warts and ringbones. Somehow or other, when the dogs were harnessing for a journey "old Grim" was sure not to be found; and upon one occasion, when he was detected hiding away in a cast off barrel, he incon tinently became lame. Strange to say he has been lame ever since, except when the team is away without him." [p. 17]

Many animals station sentinels $\{$ by $\}$ day and some by night. As examples the chamois, the marmoset. Jays and Crows may be mentioned. It is said that geese at night always station a watch which is relieved at intervals during the night; and DeKay mentions the habit of Quails of arranging themselves on the ground in a circle by night, with their heads outward.

\{Gibbon mentions the habit of the male vicuna to warn the females. Exploration 16. ${ }^{45}$

Many animals provide magazines on which to subsist during the winter. This appears to be the result of a long process of reasoning; of which the impossibility of obtaining supplies during such period, the amount necessary, the manner of bestowing it, and the kinds of provisions which are not perishable may be the most obvious. If all these points were not heeded the consequence would be fatal. To satisfy present hunger is comparatively a simple matter, but to anticipate distant wants, the exercise of intelligence is requisite. The ant, the bee, the squirrel, the rat, the wood chuck and the beaver are distinguished instances of this forethought.

In a recent number of the London Quarterly, $\{\text { January } 1857\}^{46}$ there is a long and curious article upon Rats, historical and anecdotal. The following is upon the authority of a Sussex clergyman[:] "Walking out in some meadows one evening he observed a great number of rats migrating from one place to another." (Read from Miscellany P. 37.). A similar in the Knickerbocker for Nov. 1843. $(\text { Read it P. 597) })^{47}$

In Stansbury [' s] Report on the exploration of the valley of the great salt lake ${ }^{48}$ (P. 193), he tells the following story of a pelican. "In a ramble round the shore" etc. (Read from Book, P. 193).

Read also from P. 207. Rhinoceros Birds. Cumming vol. 1, 292. Note. ${ }^{49}$ 
Dr. Kane thus speaks of the disease which took off a number of his dogs before the first Arctic winter was over, which [p. 18] was doubtless occasioned by the absence of light. He says (1. Kane[' ]s Arctic Expedition, 157 ${ }^{50}$ "The[ir] disease is as clearly mental as in the case of any human being. The more material functions of the poor brutes go on without interruption; they eat voraciously, retain their strength and sleep well. But all the indications beyond this go to prove that the original \{epilepsy\}, which was the first manifestation of brain disease among them, has been followed by a true lunacy. They bark frenziedly at nothing, and walk in straight and curved lines with anxious and unwearied perseverance $+++{ }^{51}$

["]So it was with poor Flora our "wise dog." She was seized with the endemic spasms, and, after a few wild violent paroxysms, lapsed into a lethargic condition, eating voraciously, but gaining no strength. This passing off, the same crazy buildup took possession of her, and she died of brain disease (arachnoidal effusion) in about six weeks." 52

Spawning grounds of fish. (Smithsonian Report, 1854, P. 288) ${ }^{53}$

Insect habitations. (Smithsonian Report, 1855, P. 139)54

There is a species of ant (red or brown) in the West Indies which builds its nest or hive in the trees, upon some branching limb, to escape its unsparing enemy the lizard; but as the lizard can ascend a tree, $\{$ (doubtful) $\}$ this was not a sufficient protection and we find that they construct covered ways of mud from the limb to the trunk, and down the trunk to the ground. (Hervey Ely ${ }^{55}$ observed one of these nests with the covered way, and lizards about the foot of the tree lying in wait.)

A dog when following his master along a road by the scent of his footsteps, comes to a fork; he goes up one fork and failing to find his scent, he returns and goes up the other fork without even putting his nose to the ground. He draws the conclusion that because he did not take the first one, he must necessarily have taken the other.

One of Mrs. Ely ['] s cats loosing [sic] her kittens. Adopted one of another cat[']s kittens. [181/2]

[The next page is written on the back of p. 181/2.]

Frogs bury themselves in the sand, and mine [?] the water to take fish.

Cic. D. N. $2.49^{56}$

But "Who is not able to admire that act related by Aristotle, and many others from him? The cranes, when $\{$ they $\}$ seeking a colder climate, fly over the sea, take the form of a triangle; but the opposing air is divided by the extreme point of this triangle made by them, $\{$ then gradually to each side as by oars and so the course of the birds is made lighter for their wings. But the base of the triangle, which the cranes make, this is employed advantageously by the [birds], ${ }^{57}$ as it were from a ship's stern; and they place their heads and necks upon the back of those flying before. But since the leader himself is not able to do so because he has not one upon whom he may rest, he flies back, that he also may rest, and one succeeds in the place of him from those 
who have rested; and this interchange is preserved in their whole flight." Cicero De Nat. Deo. 11.49

"The wild goats in Crete, when they have been wounded with poisoned arrows, seek an herb, which is called dittany, which when they have eaten, the arrows are said to fall from the body." Cic. N. D. 2.49

And the deer a short time before parturition purges herself with a certain herb which is called seselis, ibid

"And these animals, which were born but a little while before, without a master, nature being the leader, seek the dugs; and are filled from their abundance." But, as we know, none of these things are fortuitous; all these are the works of a provident and skilful nature." ibid ${ }^{58}$

What can I say, how much reason appears in the beasts for the perpetuation and preservation of their kind? + + What may I say, how great is the love of beasts in educating and guarding these, when they have brought forth; and even to death so long as they are able, they defend them. Ibid

[Unnumbered back of p. 181/2 ends here.]

It will not be considered necessary by you that examples of acts of the Mutae exhibiting intelligence should be multiplied any further. Not but that a well sustained argument must rest upon a wide foundation of attested facts; but for the reason that each one of you can recall on the instant a sufficient number of these facts which have fallen under your own observation to present fully the main question. A word here upon the volition of the Mutae. Dr. Hickock [sic] in his Rational Psychology ${ }^{59}$ denies to them the possession of the will in its strict philosophical sense. His argument on this point is so loaded with metaphysical subtleties that it is hard to plough through his periods [?] without a broken head; but the conclusion is a sort of necessity because individual responsibility is annex' $d$ to the possession of the will. Now we must oppose to all this special pleading the simple fact that the Mutae all and, singular, do put forth a will every day of their lives; that they do have power to get up or lay down, to eat or to drink, to bark or to sing, to play or to fight, to lay in wait for prey or to go forth in quest of it. If I call my cat, she comes or not as she pleases, because I have no coercive power over her will. If I call my dog, he comes, for the reason that his will is subordinate to mine, under the influence either of fear or affection, but in both cases they have an independent choice. ${ }^{60}$ The resolution of this question must after all be perfectly simple. A motive or inducement to do a certain act enters the mind of a dog. Unless he has a choice whether to do the act or not, he would necessarily do every act on the instant the motive arose, without the least power of restraint. Carry out this mode of action and he would lose his life every hour in the day. Without a will their acts would not only be fitful but senseless. Again all happiness depends wholly upon the possession by every animal of the control of himself. [p. 19] Without the power of choice to do or not to do a particular thing the lives of the Mutae would be divested of all possibility of happiness. A proposition denying to them volition is so unnatural; and so contrary to all observation, that it hardly requires a refutation.

Assuming then that the Mutae have the power of perception and volition, have they also the power of reflection; the ability to compare one fact with another, and to draw conclusions; the 
ability to discover the adaptation of means to an end. How came the Tiger to splash the water with his tail, if he did not know what every school boy knows, that it would draw the attention of every fish within a reasonable distance, and attract the most eager at once to the spot. ${ }^{61}$ How came he to use this knowledge unless he had an end to achieve by the act? How came old Grim to hide, when the other dogs were being harnessed for what he knew by experience to be a tiresome journey; and when this expedient failed, how came he to go lame without any other cause than his dislike to the harness? I take it that it is at least the province of the human mind, to reason soundly upon facts; and there is no way of evading the plain and necessary interpretation of these acts. Upon analysis they present all the elements of reasoning from cause to effect, together with the demonstration itself of applying the means to effect the end. How came the fox to feign death when he found it impossible to get out of the coop except by the aid of the farmer, unless he knew that it was only in the capacity of a dead fox, the farmer would ever allow him to leave the scene of his spoilation? And yet to devise this plan was worthy [?] of a foxes mind, and rather taxes our confidence in a foxes nerves.

Now it is not at all necessary, for the purposes of this [p. 20] argument, to advance a single step beyond one of these examples to dispose of the main question. If it is proved that a tiger is endowed with a principle which is capable of memory, of perception, reflection and volition, then it follows that the exclusive possession of the thinking principle by man is at once, and forever exploded. The position so long, so unjustly and so arrogantly maintained that man is the only created being capable of reasoning, is found to be untrue in fact. But the research can be extended \{through\} the several species of the four orders with the same result so far as our knowledge of the ways and habits of each will enable us to prosecute it. With this great barrier, not of philosophy, but of human pride, removed, we shall be prepared to reconstruct the science of mind upon a wider, and a more enduring foundation. With the mind of man, preeminent in its endowments and immeasurably above the mind of the other species, standing at the head, and the great exemplar of the thinking principle; but ranging below it in a scale of gradation we shall find the mind of the elephant, the lion and the beaver; the mind of the bee, the ant, and the humming bird; the mind of the nautillus [sic], of the fish, and even of the oyster, each adapted to the sphere prescribed to the species by the structural organization of the individual creature; and all alike exhibiting, under different modifications, the possession of that great and mysterious principle of intellect, which God created, and bestowed upon the animal kingdom as the crowning act of his power and wisdom.

I am now compelled to leave this, the most important branch of the subject, and which has been but little more than introduced, for the want of time.

Another question presents itself in this connection which [p. 21] requires a careful presentation to render the conclusions I have attempted to establish of any real value; and that is, whether the difference in degree between the powers of the human intellect, and the intellect of the most intelligent of the Mutae is not so great, as to render the difference substantially a radical one; and this difference as you descend the scale increases so rapidly as to render it extremely necessary to preserve the link unbroken which connects the next highest, with the highest species. The hiatus between man and the species next below him is far greater than can be found in any other part of the scale; and it is sufficiently great to suggest, at least, the idea, that some intermediate species, and perhaps several of them, have dropped out in the course of the early ages, or that some existing species have been degraded beyond redemption. But with such conjectures we 
have nothing to do. I shall content myself, however, with suggesting, that the difference in intellectual power $\{$ in degree $\}$ between the highest specimens of man, and the lowest, between Daniel Webster, and a Bushman, is very probably as great, as between a Bushman and his neighbor the elephant; and so on down to the end of the scale. The volume of the mind does not depend upon the size of the body, neither must a principle, to be mind, come up to a certain standard of power. The true question is first, what \{qualities are $\}$ radical to mind, and to this I should answer, perception, memory, $\{$ imagination $\}$ reason, and a will. There may be other essentials, but the degree of the strength of each is immaterial. Then the next question is can the ant, for example, perceive, remember, reason, and will. Cicero answers this question as follows. "In formica non modo sensus, sed etiam mens, ratio, memoria." \{ (De Nat. Deo., III. C. 9) $\}$ Pliny also answers it. "Et its Republicae ratio, memoria, cura." (Plin. Nat. Hist., Lib. XI. C. 36). ${ }^{62}$ If then the ant manifests these qualities which are radical to mind, he has a mind whether we concede it to him or not. I am satisfied that a full [p. 22] examination of this branch of the subject will not vary in the least the main conclusion.

There are several other questions which remain to be considered and which I shall merely refer to. One is articulate speech as a characteristic of the human race, whether it implies the possession of any principle which separates man radically from the other species. There appears to be nothing to justify the affirmative of this position. Articulate speech is an incidental result of structural organization. Cuvier says (An. King. P. 47), "Man is preeminently distinguished in the organ of voice; of all the Mammalia, he alone possesses the faculty of articulating sounds; its probable cause being the form of his mouth, and the great mobility of his lips." ${ }^{63}$ But all the Mammalia alike have the organ of voice. He says elsewhere, (ib. 43), "The organ of voice (in the Mammalia) is always on the upper extremity of the trachea; a fleshy curtain, called the velum palati, establishes a direct communication between their larynx and nasal canal. ${ }^{64}$ Although the Mutae have not articulate speech, it does not follow that they have no mode of communication with each other. Thought is anterior to all language, and not necessarily dependent upon it. Every man must be conscious of mental processes and of reasoning from premises to conclusions without the use of words. From facts within our knowledge it would not be difficult to prove, I think, that the Mutae are able to communicate their thoughts to each other independent of the great fact that all social life would be impossible without it.

It is frequently stated as an objection to the views here presented, that man alone is a progressive animal; while the attainments of the Mutae are stationary from generation to generation, and from age to age. This is true in some senses, but it is not true in the precise sense in which it is generally understood. [p. 23] Man, indeed, progresses in knowledge from generation to generation, but yet the limits of the human understanding have not been advanced one hairs breadth within man's historical period. All the capacities of the entire race of man existed potentially in the first human pair. Man progresses in knowledge not only as an individual, but from age to age. He alone is able to perpetuate his intellectual achievements by means of a written language, thus making every discovery a foundation on which to mount up to a new discovery. This gives to him an advantage almost inconceivably great, and is sufficient of itself to account for the wide distance between him, and the next highest species. Notwithstanding portions of the human race have thus risen to the heights of civilization, other portions, as the Bushman and the Hotentot, still sit in the darkness of ignorance and intellectual imbecility. The Bushman, however, is of the human genus; and logically, the point of comparison between man 
and the species next below him, commences with the Bushman just as legitimately as with the European. The domestic animals furnish us with examples of the improvability of several species from generation to generation; and every individual creature necessarily improves with its growth and experience. \{Pointer dogs, inherited instincts. ${ }^{65}$ Can any one assert that the bee and the ant do not teach their offspring, and thus hand down traditionary [sic] knowledge \{ acquired within their sphere of life, from generation to generation? We do not, at all events, know the contrary; and it is just as inadmissible, without proof, to assume the one as the other. But to recur to the point from which we started; that man progresses in knowledge only, and not in the ultimate strength of his capacities, we can make this apparent by contrasting the great intellects of the ancient and modern world. Compare Socrates, Plato and Aristotle with Bacon, Erasmus and Burke; Alexander and Caesar with \{Frederick the Great and Napoleon (and Wellington); [p. 24] Homer \{ and Aeschylus $\}^{66}$ with Shakespeare and Milton; Euclid and Archimedes with Newton and Kepler, and we do not find the modern man, developed under the accumulated knowledge of ages, one shade beyond his prototype in the strength of his genius or the profundity of his intellect.

With a slight reference to one other topic, I am done. Could the propositions advanced at the commencement of this inquiry be established and believed by the human race, it would result in great good to man, and to the animal races below him. As it is, we regard these races as created primarily and altogether for our convenience. We deny them all rights, and ravage them with wanton and unmerciful cruelty. The annual sacrifice of animal life to maintain our race is frightful, in its very excess, beyond our just wants as carnivorous by creation. If the human race should maintain its present attitude towards the Mutae, and progress in numbers and civilization for several centuries, the habitat of many species would contract until they would be finally extirpated. But this will never happen. God created every creature primarily for the creature himself. The gift of life was designed for him alone who received it at His hand, subject to the law of relation established between the species. He has adjusted a balance between these races, and given to each the vital and vegetative power necessary for its perpetuity. Every species is surrounded alike with the means of life, and the means of enjoyment; and no one is made dependent upon the will of another. He has also bestowed rights upon every species, which no other may violate and escape the consequences. I have often thought $\{$ that $\}$ the ancient philosopher, whoever he was, who first promulgated the doctrine of the transmigration of souls, was worthy of immortal renown. Such a shield for the [p. 25] protection of the inferior animals against the rapacity of man was never before devised by human genius, and perhaps will never be again. Great is the pity, then, that like the shield of Achilles, it now exists only in poetry. ${ }^{67}$ [p. 26]

\section{Supplemental ${ }^{68}$ \\ "Utinam tam facile vera invenire possim, quam falsa convincere." Cic. De. Na. 1.32. ${ }^{69}$}

The position intended to be taken with reference to the word instinct, is, first, that for all that class of acts in man which are called instinctive, (if rightly so called, ) and by Hamilton, the work of an unknown agent, we have a corresponding class of acts among the Mutae which must in like manner, and for precisely the same reasons, be called instinctive; while all other acts of the Mutae are referable to an intellectual principle, the same as all the other acts of the human species; except in both cases those acts which are strictly involuntary. For example, the act of a new born infant in nursing, which as a first act was done without foreknowing absolutely the end 
to be gained, is called instinctive; so in like manner the first act of a new born animal in nursing must be called instinctive. There are also other acts of the human mind which we call "instinctive beliefs," — "instinctive judgements," — "instinctive cognitions," which fit is asserted) we cannot explain as the result of anterior mental processes, and therefore they are classed under the head of instinctive acts. Now in what is called the "sagacity" of the Mutae we have evidences of a corresponding class of acts, and which, for the same cause, if the others are rightly so called) must be referred to the same unknown agent "which performs blindly and ignorantly a work of intelligence and knowledge." After thus isolating a limited number of the so called \} unexplainable acts of both man and the Mutae, we have left the great body of the acts of both which manifest the existence and operation of an intelligent principle. If the dividing line between those limited acts which are not supposed to be ) explainable by any anterior mental process, and those which are explainable by anterior mental processes, in both man and the Mutae, could be maintained in its integrity, that is admitting corresponding acts and causes in both man and the inferior animals, then there would be no occasion to inquire whether the use of the term instinct was legitimate in connection with these acts, for two reasons: first, that no ground is presented on which to assert a [p. 27] radical difference between the thinking principle of man and the Mutae; and second, that in discussing these subtle phenomena you enter a department of intellectual science in which it is extremely difficult to make any sensible advance, or reach any very satisfactory result.

But while certain acts of man, which cannot as it is claimed) be referred to anterior mental processes, are called instinctive, all of his other acts are left to rest upon the ordinary basis of mental causes. Not so however with the Mutae, the term instinct was introduced to account for their intelligent acts, and its definitions are made broad enough to include and explain all of their acts; and thus we have no dividing line between instinct and reason, no defined point where instinct ceases, and reason begins, leaving each one to concede reasoning powers to the Mutae in such measure and degree or none at all as his mere fancy may dictate. It is impossible therefore to assign to the endowments of animals any fixed place in the intellectual scale, while we recognize the principle of instinct as at present defined.

Let us inquire then, first, into the origin and introduction of the term instinct, and the position of eminent naturalists in relation to its meaning and limits; and, second, whether there is such a principle or agent as instinct, according to received definitions [Morgan's emphasis].

This term, as now used to explain the intelligent acts of the Mutae, is evidently of modern introduction. Its etymology does not suggest the present meaning. Instinguo, from whence instinctus, is of limited signification, meaning to instigate, incite, impel, leaving the cause of the instigation, suggestion or impulse to be explained from without; while the present term includes both the fact and its cause. It is not a Greek word; and its synonym $\pi \alpha \rho o \rho \mu \alpha o$ [parhormao], whence $\pi \alpha \rho о \rho \mu \eta \sigma i \zeta$, [parhormesis] has precisely the same signification, to impel, incite, urge. ${ }^{70}$ As used by the Latins, it \{was employed in its strict etymological sense, and \} applied to man; and as far as I can discover, was never applied to the acts of the Mutae (Cicero, De. Div., Lib.1, C.18; Quint[illian], Ins. Or., L. 12, C.10, §24; Aulus [p. 28] Gell[ius], 17.20; Tacitus Hist., 1.22, ib. 68). ${ }^{7} 1$ The ancient estimate of the endowments of the Mutae was more liberal and comprehensive than the present. They used the same terms in characterizing their intelligent acts [as] they did with reference to those of man. Pliny thus speaks of the ant (Plin. Nat. Hist XI 36[)] 
"Et its Republicae ratio, memoria, cura"; and Cicero, "In formica non modo sensus sed etiam mens, ratio, memoria." See also Virgil on the same subject (Aeneid IV.402). The word "intellectus" is used by Pliny in connection with the elephant (ib 8.1.5). As this word [instinct] is no longer used in its original sense of a simple instigation or impulse, and we do not find it employed by the ancients in any other, it is reasonable to conclude that it is a modern term. ${ }^{72}$

The history of its modern introduction I have not the facilities for tracing out. Locke, whose essay on the understanding appeared in $1687,{ }^{73}$ does not use the word at all, although he has frequent occasion to speak of the endowments of the Mutae; and besides his system of intellectual philosophy runs counter to the claims of instinct as he denies all innate ideas, fin opposition to Descarte [sic] who affirmed the existence of innate ideas $\}.{ }^{74}$ Dr. Reid whose philosophy appeared in 17 [blank] ${ }^{75}$ is charged by some writers [?] as having been unfortunate in the use of the terms "Common Sense" and "instinct" which may perhaps furnish some evidence that this term was first brough[t] into conspicuous use in intellectual philosophy by him. The objection raised was that the term was used to explain some of the acts of the human mind, and not that it was wholly insufficient to account for the acts of the Mutae. He applies the term to explain a large class of the acts of man, and in effect, the whole of the acts of the Mutae.

If we compare the several definitions of the term instinct as used both by naturalists and intellectual philosophers, it will appear that they all run in the same rut, and, with immaterial qualifications, are all taken from the same original.

Reid says "Instinct is the habitual power of producing effects like contrivances of reason, yet so far beyond the intelligence and experience [p. 29] of the agent as to be utterly inexplicable by reference to them" (Reid's Active Powers, P. [blank]).

In L[or]d. Monboddo "Ancient [sic] Metaphysics" is the following. "Instinct is a determination given by Almighty Wisdom to the mind of the brute, to act in such or such a way, upon such or such an occasion, without intelligence, without knowledge of good or ill, and without knowing for what purpose he acts."

Hale (Origin of Mankind) says "Many analogical motions in animals, though I cannot call them voluntary, yet I see them spontaneous, I have reason to conclude are not simply mechanical + + + The sagacities and instincts of brutes, the spontaneousness of many of their motions, are not explicable without supposing some active determinate power, connected to and inherent in their spirits, of a higher extraction than the bare natural modifications of matter." 78

Cuvier (An. King. Intro.) ${ }^{79}$ ["] The only method of obtaining a clear idea of instinct is by admitting the existence of innate and perpetual images or sensations in the sensorium which causes the animal to act in the same way as ordinary or accidental sensations usually do. It is a kind of perpetual vision or dream that always pursues it, and it may be considered in all that relates to its instinct as a kind of somnambulation." ${ }^{80}$

There is another general view of instinct which still prevails to some extent, and which I believe is substantially the idea of Des Cartes, and which reduces the Mutae to mere physical machines, namely "That their acts are in obedience to a law impressed upon their vital constitution, which impells [sic] them not only to perform certain acts necessary for the preservation of the species, but also to do the same things in the same way from generation to generation." ${ }^{11}$ 
In the Encyclopedia Brittanica [sic] (Title Instinct) is the following definition. Instinct is "a certain power or disposition of mind, by which [p. 30] independently of all instructions or experience, without deliberation, and without having any end in view, animals are unerringly directed to do spontaneously whatever is necessary for the preservation of the individual, or the continuance of the kind. + + Instinctive actions have a cause, viz. the internal impulse by which they are spontaneously performed, but they cannot be said to have a motive, because they are not done with any view to consequences. ++ The bee and the beaver are endowed with an instinct which has the appearance of foresight. They build magazines and fill them with provisions, but the foresight is not theirs." 82

${ }^{\text {Sir }}$ William Hamilton (Ham. Phil. Higher Ed. 62) has given us a definition which contains the pith of all previous ones, and has the singular merit of being intelligible. He says, "An instinct is an agent which performs blindly and ignorantly a work of intelligence and knowledge. ${ }^{18}$

See Paley[']s Moral Philosophy on Animal instinct. ${ }^{84}$

\section{Notes}

1. Donald A. Dewsbury, Comparative Psychology in the Twentieth Century (Stroudsburg, PA: Hutchinson Ross, 1984). Dewsbury writes: "I have chosen to begin the story [of comparative psychology] in 1894 ... a as good a year as any and somewhat better than most" (p. 44).

2. William James, Principles of Psychology, 2 vols. (New York: Holt, 1890).

3. Timothy D. Johnston, "Three Pioneers of Comparative Psychology in America, 18431890: Lewis Henry Morgan, John Bascom, and Joseph LeConte." History of Psychology, in press.

4. Imre Lakatos, The Methodology of Scientific Research Programmes, eds. John Worrall and Gregory Currie (Cambridge, England: Cambridge University Press, 1978).

5. For biographical information on Morgan, see Bernhard J. Stern, Lewis Henry Morgan: Social Evolutionist (Chicago: University of Chicago Press, 1931); Carl Resek, Lewis Henry Morgan: American Scholar (Chicago: University of Chicago Press, 1960); Thomas R. Trautmann, "Morgan, Lewis Henry," American National Biography Online, http://www.anb.org/articl es/14/14-00423 .html [accessed September 1, 2001] . Morgan's contributions to anthropology are discussed in Meyer Fortes, Kinship and the Social Order: The Legacy of Lewis Henry Morgan (Chicago: Aldine, 1969); Elman R. Service, "The Mind of Lewis H. Morgan," Current Anthropology 22 (1981): 25-43; Thomas R. Trautmann, Lewis Henry Morgan and the Invention of Kinship (Berkeley \& Los Angeles: University of California Press, 1987); Elizabeth Tooker, "Lewis H. Morgan and His Contemporaries," American Anthropologist 94 (1992): 357-375; Gillian FeeleyHarnik, "'The Mystery of Life in All Its Forms': Religious Dimensions of Culture in Early American Anthropology," in Religion and Cultural Studies, ed. Susan L. Mizruchi (Princeton, NJ: Princeton University Press, 2001), 140-191. Trautmann's book includes a complete bibliography of Morgan's publications (pp. 267-271). An inventory of the Morgan papers at the University of Rochester is available at http://www.lib.rochester.edu/ rbk/MORGLH. stm

6. Lewis Henry Morgan, League of the Ho-de-no-sau-nee, or Iroquois (Rochester, NY: Sage \& Brother, 1851; reprint: New York: Corinth Books, 1962). 
7. Aquarius [Lewis Henry Morgan], "Mind or Instinct: An Inquiry Concerning the Manifestations of Mind by the Lower Animals," The Knickerbocker 22 (1843): 414 420 (Nov.), 507-515 (Dec). Morgan apparently submitted this article under a pseudonym. The Morgan papers contain a letter from Lewis Gaylord Clark, editor of The Knickerbocker, dated 30, October 1843, and addressed to "C. Shepherd, Esq.," confirming "that the first part of your paper on Animal Instinct, or Mind, is in the November No. of the Knickerbocker, and that the second part will have the 'place of honor,' the first place, in the December issue." In the left-hand margin of this letter, Morgan wrote: "I sent the articles in the name of my friend C. E. Shepherd." No other reference to Shepherd appears in any of Morgan's papers, nor is he listed in any biographical indexes. Lewis Henry Morgan Papers, Correspondence, Box I (1839-1854), Rush Rhees Library, University of Rochester, Rochester, NY.

8. Lewis Henry Morgan, Ancient Society, or Researches in the Lines of Human Progress From Savagery Through Barbarism to Civilization (New York: Holt, 1877). On the evolutionary nature of Morgan's views, see Adam Kuper, "The Development of Lewis Henry Morgan's Evolutionism," Journal of the History of the Behavioral Sciences 21 (1985): 3-22.

9. Knight Dunlap, "Are There Any Instincts?" Journal of Abnormal Psychology 14 (1919): 307-311; Zing-Yang Kuo, "Giving Up Instincts in Psychology," Journal of Philosophy 18 (1921): 645-664. See David L. Krantz and David Allen, "The Rise and Fall of McDougall's Instinct Doctrine," Journal of the History of the Behavioral Sciences 3 (1967): 326-338.

10. Compare, for example, the introductions of this manuscript and Morgan's 1868 chapter. In the published version, Morgan's criticisms of instinct were less pointed, and he expressed some of his views on animal reason more cautiously, possibly to deflect theological criticism.

11. George J. Romanes, Animal Intelligence (London: Kegan Paul and Trench, 1881); C. Lloyd Morgan, An Introduction to Comparative Psychology (London: Walter Scott, 1895). See Robert Boakes, From Darwin to Behaviourism: Psychology and the Minds of Animals (Cambridge, England: Cambridge University Press, 1984), chap. 2, for a discussion of this issue.

12. Morgan's ideas about animal psychology are usually mentioned at least briefly in anthropological writings on his work. Stern, Lewis Henry Morgan, chap. 4, considers them in rather more detail and concludes that his work has "not received the acknowledgement that it deserves in the literature of animal psychology" (p. 108). See Charles W. Tolman, "Lewis Henry Morgan's Animal Psychology and Historical Materialism," Nature, Society and Thought 3 (1990): 261-267. More details about the relation of Morgan's ideas to those of his contemporaries will be found in Johnston, "Three Pioneers."

13. Resek, Lewis Henry Morgan, p. 61; "Origin and History of the 'Club,- Morgan Papers, Box 22, Folder 43, Rush Rhees Library, University of Rochester, Rochester, NY. On the Pundit Club's membership and topics of discussion during this period, see Blake McKelvey, "When Science Was On Trial in Rochester: 1850-1890," Rochester History 8 (1946): 1-24.

14. Lewis Henry Morgan, "Notes of a visit to Marquette, L[ake] S[uperior]. August, 1860," Morgan Papers, Manuscript Journals, Vol. 4., Rush Rhees Library, University of Rochester, Rochester, NY. 
15. Lewis Henry Morgan, The American Beaver and His Works (Philadelphia: J. B.

Lippincott, 1868; reprint: New York: Burt Franklin, 1970).

16. Morgan, "Mind or Instinct."

17. Morgan, The American Beaver, 248-284.

18. Ibid., 284.

19. Morgan, Ancient Society.

20. Thomas R. Trautmann and Karl Sanford Kabelac, The Library of Lewis Henry Morgan (Philadelphia: American Philosophical Society, 1994).

21. In the manuscript, the words "will answer all the ends it was designed to subserve" are placed in parentheses, but not crossed out, and "disposes of the whole subject" is written above the line. It is not clear which Morgan intended as his final wording.

22. The words "particulars and in general" are lightly crossed out, and "analysis and synthesis" is written in pencil above them.

23. The "four divisions" of the animal kingdom, from Cuvier, comprise the Vertebrata, Mollusca, Articulata, and Radiata. Georges Cuvier, The Animal Kingdom, Arranged in Conformity With Its Organization (New York: Carville, 1823). See Thomas R.

Trautmann and Karl Sanford Kabelac, The Library of Lewis Henry Morgan (Philadelphia: American Philosophical Society, 1994), entry C247. To check Morgan's references to Cuvier, I used a later and more readily available edition: The Animal Kingdom, Arranged According to its Organization (London: Henry G. Bohn, 1853; reprint: New York: Kraus Reprint Co., 1969). Morgan's understanding of animal taxonomy, anatomy, and physiology is based very largely on Cuvier.

24. Cuvier, The Animal Kingdom (1853), 328.

25. Ebenezer Emmons, Agriculture of New York, 5 Vols. (Albany, NY: C. Van Benthuysen \& Co., 1846-1854), part of the series Natural History of New York (Div. 5). Trautmann \& Kabelac, Library of Lewis Henry Morgan, entries C315 and C750.

26. This description is taken almost verbatim from Cuvier, The Animal Kingdom (1853), 142. For an account of the unusual respiratory system of birds and its adaptation for flight, see M. R. Fedde, "Respiration," in Avian Physiology, ed. P. D. Sturkie (New York: Springer-Verlag, 1976), 122-145.

27. Cuvier, The Animal Kingdom (1853), 5.

28. The most likely source of this quotation is John Abercrombie, Inquiries Concerning the Intellectual Powers, and the Investigation of Truth, 2d ed. (New York: Harper \& Bros., 1839); Trautmann \& Kabelac, Library of Lewis Henry Morgan, entries C4-05. The exact wording does not appear in this work, but there is one passage that conveys precisely the same meaning: "I do not say that the mind possesses distinct faculties, which we call memory, abstraction, imagination, and judgment . . . but simply, that, in point of fact, the mind remembers, abstracts, imagines, and judges. ... [B] [eyond the simple facts we know nothing, and no human ingenuity can take us one step farther" (p. 88). Morgan may well have quoted the passage from memory and added a footnote identifying the author as an afterthought.

29. Sir William Hamilton, Discussions on Philosophy and Literature, Education and University Reform (London: Longman, Brown, Green and Longmans, 1852). The quotation does appear in that work, but on p. 51, not p. 138. It may be that Morgan used a different edition or that he simply made a mistake in noting the page number. Emphases are Hamilton's. 
30. Hamilton, Discussions on Philosophy and Literature, 96 (not p. 40).

31. Here, as in other places in the manuscript, Morgan uses the term radical with its older meaning of basic, or foundational, rather than in the more modern sense of marked or dramatic.

32. An almost illegible marginal note in pencil beside the previous paragraph may read: "Cat showing its mouth to S. P. Ely to take out the stuck bone of a turkey from his throat."

Samuel P. Ely was the nephew of Morgan's good friend Hervey Ely (see note 55) and an associate in his railroad investments in the Midwest. Lewis Henry Morgan, The American Beaver, xi.

33. Marginal note: "apportionment [?] of the principle."

34. This quotation does not appear in Hamilton's Discussions on Philosophy and Literature, as Morgan's citation implies. It is found in "Editor's Supplementary Dissertations," in The Works of Thomas Reid, ed. Sir William Hamilton (Edinburgh, Scotland: Maclachlan \& Stewart, 1846/1863), 761. My page reference is to the sixth edition of this work (1863; reprint: Bristol, England: Thoemmes Press, 1994); Morgan would obviously have used an earlier edition. See also Francis Bowen, The Metaphysics of Sir William Hamilton (Boston: John Allyn, 1872), 505 (footnote).

35. This sentence begins a rather confusing passage in which it is hard to sort out Morgan's argument. His point seems to be that even if instinct names a process not accessible to consciousness, the same may also be true of reason, under some conditions. However, Hamilton was not addressing that issue. His definition of instinct occurs in an assessment of one feature of Reid's "common sense ideas," namely that their truth is felt intuitively rather than being consciously understood, which is not the same as asserting that mental processes are (or are not) consciously understood. Note also that there is no "second" corresponding to the "First" that opens this sentence.

36. This curious choice of word comes from Cuvier, who wrote: "Man has the faculty of associating his general ideas with particular images more or less arbitrary, easily impressed upon the memory, and which serve to recall the general ideas which they represent ... . When its images relate to that of sight, they are called hieroglyphics." Cuvier, The Animal Kingdom (1853), 19. Morgan lightly crossed through the word, suggesting that he was not entirely comfortable with it.

37. The word mind is written in pencil just above the word soul, but the latter is not crossed out.

38. Here Morgan originally wrote mind, crossed it out and inserted intellect, then crossed that out and inserted "the principle of intelligence."

39. I cannot identify the source of this quotation. The wording strongly implies a New York (or at least New England) author, because the state is not specified. It might refer to a work by the Rev. John Murray (1741-1815), a Boston preacher and founder of the Universalist church. However, none of Murray's published works has the word creation in the title, nor does the style of his writing suggest that he would have published an anecdote of this kind. His Letters, and Sketches of Sermons, 3 vols. (Boston: Joshua Belcher, 1812) does not contain the quoted passage. Morgan's uppercase $\mathbf{J}$ is almost identical to his uppercase I, but I can find no reference to a "Rev. I. Murray" from the relevant time period.

40. I am unable to identify either Dr. Burrows or Dr. Abell. Dr. Burrows's lecture may have been given at the Albany Institute, but no record of it has been preserved in the institute's 
archives. Morgan was elected a "corresponding member" of the institute in 1868, although he could have attended meeetings in earlier years (Jennifer Benedetto Beals, Albany Institute of History and Art, personal communication, 15 March 2002). Morgan's election is recorded in the minutes of a meeting of the Institute on 4 February 1868, Proceedings of the Albany Institute 1 (1868): 72.

41. In The American Beaver, 269, Morgan attributes this anecdote to "Coral C. White, of Aurora, New York, who carried out the fox. His veracity is unimpeachable."

42. James E. De Kay, Zoology of New York, 5 vols. (Albany, NY: C. Van Benthuysen \& Co., 1842-1844), part of the series Natural History of New York (Div. 1). Trautmann \& Kabelac, Library of Lewis Henry Morgan, C750.

43. William Lewis Herndon and Lardner Gibbon, Exploration of the Valley of the Amazon, Made Under the Direction of the Navy Department, Volume 1 (Washington, DC: R. Armstrong, 1853-1854), 312-313. The story (quoted at length in Morgan, The American Beaver, 261) is of a tiger that splashes its tail in the water to attract fish, which it then seizes and eats.

44. Elisha Kent Kane, Arctic Explorations: The Second Grinnell Expedition in Search of Sir John Franklin, Volume 1 (Philadelphia: Childs \& Peterson, 1856), 149ff.

45. Herndon and Gibbon, Exploration of the Valley of the Amazon, 16, has nothing of relevance, but the following passage appears on p. 59: "[Vicunas] go in herds of ten or fifteen females, accompanied by one male, who is ever on the alert. On the approach of danger he gives warning by a shrill whistle, and his charge makes off with the speed of the wind."

46. This reference is to an anonymous, untitled review of three books in the London Quarterly Review 101 (1857): 68-78. The sentence quoted by Morgan appears on p. 72 and is taken by the reviewer from Edward Jesse, Gleanings in Natural History, 8th ed. (London: John Murray, 1854). The two following sentences read: "[The clergyman] stood perfectly still, and the whole assemblage passed close to him. His astonishment, however, was great when he saw amongst the number an old blind rat, which held a piece of stick at one end in its mouth, while another had hold of the other end of it, and thus conducted its blind companion." The review contains several other examples demonstrating "the sagacity of the rat," including (on p. 72) the animal's use of its tail to take oil out of a long-necked flask (see note 47). The reference to "Miscellany p. 37" is unclear; p. 37 of this issue occurs in a long review of several books on British ferns, and there is no section titled "Miscellany."

47. The Knickerbocker 22 (1843): 597. This brief report is from "our correspondent who writes upon the 'Manifestation of Mind in Animals- and describes the behavior of three rats drinking oil from a long-necked flask. One dips the tail of another into the flask and gives it to the third to drink; then they change places. The report is in the December issue, not the November issue, but the page on which it appears is mistakenly labeled "November" at the top, evidently a printer's error. The correspondence is in reference to Aquarius [Lewis Henry Morgan], "Mind or Instinct."

48. Howard Stansbury, An Expedition to the Valley of the Great Salt Lake of Utah (Philadelphia: Lippincott, Grambo \& Co., 1855). The passages on pp. 193 and 207 describe observations that Morgan interpreted as evidence for altruism in pelicans and for maternal protectiveness in gulls, respectively. They are quoted in full in Morgan, The American Beaver, 272, 273 (footnote). In this section of his book Morgan discussed 
various altruistic qualities in animals and wrote: "For the possession of these qualities ... they are entitled to our regard" (p. 272).

49. I cannot identify the reference to "Rhinoceros birds. Cumming, vol. 1, 292. Note." The only plausible multivolume work by an author named Cumming prior to 1857 is William Fullerton Cumming, Notes of a Wanderer in Search of Health, Through Italy, Egypt, Greece, Turkey, Up the Danube, and Down the Rhine, 2 vol. (London: Saunders and Otley, 1839). Although this travelogue does mention various animals in passing, a search through the text reveals no mention of rhinoceros birds, nor is the identity of this species clear. The rhinoceros hornbill (Buceros rhinoceros) is native to Southeast Asia, but there seems no reason that Morgan should have mentioned it in this context. The reference may be to an African oxpecker (Buphaga spp.), which cleans parasites from the backs of large animals, including the rhinoceros; Morgan might have used it as an example of altruism, which would be consistent with his other examples in these two paragraphs, although its behavior can undoubtedly be explained more simply.

50. Kane, Arctic Explorations, 157. The passage quoted also appears in Morgan, The American Beaver, 264-265.

51. Marginal note: "Ant Lion. Emmons Ag vol. 5, p. 186-see 193. Ant Cuv. 456, Bees Cuv. 463." References are to Emmons, Agriculture of New York and Cuvier, Animal Kingdom.

52. Marginal note: "Elephants in the East Indies pile up timber under training, and go back a distance to see if it is straight and true, and if not they straighten the pile and repeat this until it is as near a true line as they can make it."

53. James J. Strang, "Some Remarks on the Natural History of Beaver Islands, Michigan," Annual Report of the Board of Regents of the Smithsonian Institution [for 1854] 9 (1855): 282-288. "It may not be deemed incredible that the present known species of fish have made these pavements [on the river bed] for spawning grounds" (p. 288).

54. J. G. Morris, "Insect Instincts and Transformations," Annual Report of the Board of Regents of the Smithsonian Institution [for 1855] 10 (1856): 137-141. "The lecturer stated and proved, that the most ingeniously constructed but of the beaver, and the most artfully contrived nest of the bird, are far surpassed by the habitations of insects" (p. 139).

55. Hervey Ely (1791-1862) was a close friend and business associate of Morgan's in Rochester (Morgan, The American Beaver, vii, footnote; Resek, Lewis Henry Morgan, 50).

56. All references to Cicero on this page are to De Natura Deoram [The Nature of the Gods]. The form of Morgan's citations, here and on MS pp. 27-29 (see notes 69-72) is idiosyncratic and does not correspond to modern conventions; citations may be to book and page numbers in the edition Morgan used rather than the usual book and section numbers. The translations are probably his own, because Morgan seems to have read Latin very well; the Morgan papers contain several of his translations of classical Latin authors. I have used the translation by P. G. Walsh, Cicero: The Nature of the Gods (Oxford, England: Clarendon Press, 1997) to identify Morgan's citations. This line occurs at 2.125 and reads: "The tradition about sea-frogs is that they bury themselves in the sand, and then make their way to the water's edge. Then the fish approach them, thinking that they are food, whereupon the frogs kill and devour them" (Walsh, Nature of the Gods, 92). The references to Cicero on the rest of this page all occur between 2.125 and 2.130 (Walsh, Nature of the Gods, 92-94). Dittany is Origanum dictamnus, a species of 
marjoram; seselis (also spelled seseli or seseleos) is hartwort, an umbelliferous plant of the genus Seseli. Deni Brown, Encyclopedia of Herbs and Their Uses (New York: Dorling Kindersley, 1995), 319; The Compact Oxford English Dictionary (Oxford, England: Clarendon Press, 1991).

57. Morgan wrote winds here, but birds is clearly the sense of the passage from Cicero. 58. Marginal note: "Here the word instinct would have been used if ever by the ancients."

59. Laurens Perseus Hickok, Rational Psychology or, The Subjective Idea and the Objective Law of All Intelligence (Auburn, NY: Derby, Miller \& Co., 1848; reprint: Schenectady, NY: G. Y. Van DeBogert, 1854). Hickok mentions the issue of animal will in a number of places; the following passages occur in a discussion of liberty (pp. 598-599): "[T]he ox selects grass, and the tiger selects flesh .... We may give the name of choice to the animal selection; but it is not because there is any approach towards a will in liberty .... the action of the most intelligent animal is as little in liberty, and as truly necessitated by previous conditions, as the [action of the] fire or the magnet."

60. The preceding two sentences ("If I call my cat . . . an independent choice.") are lightly crossed out, and the word will is written in the margin

61. This is the "story of Herndon's tiger," in note 43.

62. These quotations are repeated on MS p. 29; for references to Cicero and Pliny, see note 72.

63. Cuvier, The Animal Kingdom (1853), 34.

64. Ibid., 28.

65. "Inherited instincts" is a reference to the widely shared belief that habitual (learned) actions could become instinctive (inherited) by sufficient repetition, a process that Darwin called use-inheritance. Morgan evidently saw this as a way in which animals could improve their capabilities over generations, just as humans do. On use-inheritance, see Robert J. Richards, Darwin and the Emergence of Evolutionary Theories of Mind and Behavior (Chicago: University of Chicago Press, 1987), 90ff.

66. In the manuscript, Eaeschylus appears as the last word on p. 24, and Aeschylus is inserted after Homer on p. 25. I assume that Morgan meant to delete the first, misspelled occurrence on the earlier page, but neglected to.

67. In urging more considerate treatment of animals, Morgan was echoing ideas that have a long history in Western thought, as discussed by Keith Thomas, Man and the Natural World: A History of the Modern Sensibility (New York: Pantheon, 1983). The concern he expressed for the preservation of habitat did not emerge until the end of the 19th century, and even then it was expressed by only a small minority of conservation-minded writers, such as Frederick Law Olmstead and John Muir; Peter J. Bowler, The Norton History of the Environmental Sciences (New York: Norton, 1992), 309 et seq. The beaver population in the area studied by Morgan has suffered a serious decline as a result of the loss of its habitat; by the mid-20th century, only a few dozen animals remained in an area where Morgan counted hundreds. Richard H. Manville, "The Fate of Morgan's Beaver," Scientific Monthly 69 (1949): 187-191.

68. Morgan's insertions in the first two paragraphs of this section (MS pp. 2728)-"if rightly so-called," "it is asserted," "supposed to be," and so on-all seem to have been made to remove any possible implication that he believed in the existence of instinct, regardless of what the writers whose ideas he was criticizing might think. 
69. Cicero, De Natura Deorum, 1.91. The translation is: "I only wish that I could divine the truth as easily as I can refute such fasehood"; Walsh, Nature of the Gods, 35. Neither the sentence nor the context in which it occurs in Cicero has anything to do with instinct, so Morgan probably intended it only to serve as an epigraph to this section of his manuscript.

70. Marginal note: "Ilapopptao to impel, excite, urge II Hapopinlats impulsion, incitation II Instiguo. to instigate, incite, impel II Instinctus. Instigated, incited, fixed, animated II Cicero, De Div, 1.18 II N. D. 2.66." The etymology of the word instinct is, as Morgan pointed out, from the Latin (instinctus, a prod or goad), but there are several terms in Greek philosophical writing that carry some of the connotations associated with the use of the word in psychology, including opwri (horme; urge or drive) and Ovo-ts (phusis; intrinsic nature). See Stephen Everson, ed., Psychology-Companions to Ancient Thought, 2 (Cambridge, England: Cambridge University Press, 1991); F. E. Peters, Greek Philosophical Terms: A Historical Lexicon (New York: New York University Press, 1967). Morgan's choice of Hapopp,ao (parhormao; to impel toward, set in directed motion) in this context includes both directed (par-) and impulsive (-hormao) elements that are often implied by the use of the term instinct. The noun Hapopwrio-ts (parhormesis; an urging on or incitement) has the same roots. The references to Cicero in the marginal note are to De Divinatione 1.18 (see note 71) and De Natura Deorum (possibly 2.163: "Hence this power or skill or natural faculty [of divination] certainly leads to knowledge of future events, and it has been bestowed by the immortal gods on man alone"; Walsh, De Natura Deorum, 106).

71. The references within these parentheses are hard to make out, I have added some punctuation for clarity. I reconstruct them as follows and in each case quote the passage that most likely interested Morgan, if possible: Cicero, De Divinatione, 1.18 ("In this latter class must be placed oracles ... uttered under the impulse [instinctu] of divine inspiration"); Quintillian, Institutio Oratoria, 12.10.24 ("And shall we call Plato an Asiatic, Plato who as a rule deserves comparison with poets instinct [instinctis] with the divine fire of inspiration?"); The Attic Nights of Aulus Gellius, 17.20; Tacitus, Histories, 1.22 ("Ptolemy ... was already urging [instinctor] Otho even to crime"), 1.68. All are in the Loeb Classical Library (Cambridge, MA: Harvard University Press, various dates). The references to Aulus Gellius 17.20 and Tacitus 1.68 are puzzling, as neither includes anything that seems relevant to Morgan's concern in this passage, namely, the application of the word instinct and its cognates to human beings.

72. The references to Pliny, Cicero, and Virgil in this paragraph are as follows (unless otherwise indicated, all are from the Loeb Classical Library). Pliny, Natural History, 9.36: "Ants also have a system of government, and possess memory and diligence"; Cicero, De Natura Deoram, 3.21: "[A]n ant has not only feeling, but also intelligence, reason, and memory" (Walsh, Nature of the Gods, 115); Virgil, The Aeneid, 4.402: "Even as when ants, mindful of winter, plunder a huge heap of corn and store it in their home . ."; Pliny, Natural History, 8.1ff: "The largest land animal is the elephant, and it is the nearest to man in intelligence [intellectus]."

73. John Locke's Essay Concerning Human Understanding was completed in 1687 but was not published until 1689 (with a publication date of 1690). James Gordon Clapp, "Locke, John," in Encyclopedia of Philosophy, Volume 4, ed. Paul Edwards (New York: 
Macmillan, 1967), 487-503; Bertrand Russell, History of Western Philosophy (London: Allen and Unwin, 1961), 584.

74. Marginal note: "Bacon does not \{appear to have $\}$ used the word instinct in connection with the endowments of animals."

75. The words Active Powers are written just above this partial date, and so the reference must be to Thomas Reid, Essays on the Active Powers of Man (Edinburgh, Scotland: Printed for J. Bell, 1788). Morgan's assessment that Reid explains all animal actions by reference to instinct is somewhat inaccurate, as Reid actually gives a rather more nuanced account than that; he does, however deny to animals the ability to reason or make moral judgments.

76. I am unable to find the quoted passage in Reid's Active Powers or in either of Reid's other major works on the mind, Inquiry Into the Human Mind (Edinburgh, Scotland: Printed for J. Bell, 1764) and Essays on the Intellectual Powers of Man (Edinburgh, Scotland: Printed for J. Bell, 1785), although there are passages in all three works that convey much the same meaning. For example: "By instinct, I mean a natural blind impulse to certain actions, without having any end in view, without deliberation, and very often without any conception of what we do." Reid, Essays on the Active Powers of the Human Mind, in Hamilton, The Works of Thomas Reid, 545. The fact that Morgan left the page number blank suggests that he may have copied this quotation from some other source, or written it from memory, and then been unable to find it in Reid's book.

77. James Burnett, Lord Monboddo, Antient Metaphysics: Or the Science of Universals, 6 vol. (London: Printed for T. Cadell; and Edinburgh, Scotland: J. Balfour \& Co., 17791799; facsimile edition, New York: Garland, 1977). The quotation appears in vol. 3 (Appendix, chapt. III), 352.

78. Sir Matthew Hale, The Primitive Origination of Mankind, Considered and Examined According to the Light of Nature (London: William Godbid, 1677). The first part of this quotation appears on p. 23, although the wording is slightly different. The original reads: "[W]hen I see many analogal [sic] motions in Animals, which though I cannot call them voluntary, yet I see them spontaneous, I have reason to conclude that these in their principle are not simply mechanical." The second part of the quotation is on p. 49; the original reads: "It is impossible to resolve Perception, Phantasie, Memory, the sagacities and instincts of Brutes, the spontaneousness of many of their animal motions into those [mechanical] Principles, nor are they explicable without supposing some active and determinate power, force, or virtue connexed to, and inherent in their Spirits or more subtile parts, of a higher extraction than the bare natural modification or texture of matter, or dispositions of Organs." Hale's book is primarily a theological dissertation on human origins, but it also contains a good deal of psychology, including discussions of the differences between the human and animal mind (e.g., section I, chap. II, 44-70; section III, chap. VI, 276-283). It is very likely that Morgan did not actually see Hale's book, because the same quotations, with exactly the same errors, appear in footnote A of the article on "Instinct" in the Encyclopedia Britannica 5th ed.; Edinburgh, Scotland: Printed for Archibald Constable, 1815, 275-285), from which Morgan quotes a definition of instinct starting at the end of this page of the manuscript (see note 82).

79. Cuvier, The Animal Kingdom (1853), 19.

80. Marginal note: "see L[or]d Brougham[']s work on the intelligence of animals." Henry, Lord Brougham, wrote Dialogues on Instinct: With Analytical View of the Researches on 
Fossil Osteology (London: C. Knight and Co., 1844); the third and fourth dialogues (p. 96-164) are both entitled "Animal Intelligence." Brougham also wrote Dissertations on Subjects of Science Concerned With Natural Theology (London: C. Knight \& Co., 1839), on which Darwin drew for information about instinct and intelligence in animals; see Richards, Darwin and the Emergence, 136-139.

81. This quotation does not seem to be from Descartes, and the ideas of species preservation and the inheritance of behavior, mentioned in the last part of the sentence, are more typical of 19th- than of 17th-century writing on animal behavior. Descartes himself rarely used the word instinct; in a letter to Main Mersenne dated 16 October 1639, he distinguished two meanings of the word, one intellectual ("the light of nature") and one that "belongs to us qua animals, and is a certain impluse of nature towards the preservation of our body, towards the enjoyment of bodily pleasures and so on." The first of these meanings contributed to his theory of innate ideas, but the second is hardly to be found at all in his work. Descartes: Philosophical Letters, Anthony Kenny (ed. and trans.), (Oxford, England: Basil Blackwell, 1981), 67. Morgan's phrasing in this paragraph ("which I believe is substantially the idea of Des Cartes") suggests that he took the quotation from a secondary source, although the idea is not inconsistent with Descartes's view of animal behavior. For example: "[Animals] have no intelligence at all, and ... it is their nature which acts in them according to the disposition of their organs. In the same way a clock, consisting only of wheels and springs, can count the hours and measure time more accurately than we can with all our wisdom." Rene Descartes, Discourse on the Method (1637), in The Philosophical Writings of Descartes, Vol. 1, John Cottingham, Robert Stoothoff, and Dugald Murdoch (trans.), (Cambridge, England: Cambridge University Press, 1985), 141.

82. "Instinct," in Encyclopedia Britannica, 5th ed. 275. Footnote A (p. 275) makes reference to "Hales's Origin of Mankind" and quotes the passages that Morgan quotes earlier on this page of the manuscript with the same errors and misspellings. See note 78.

83. Hamilton, The Works of Thomas Reid, 761. See note 34.

84. 84. This line is written in pencil and refers to William Paley, The Principles of Moral and Political Philosophy (London: Printed for R. Faulder, 1785; facsimile edition, New York \& London: Garland, 1978). In Book I, chapter V, Paley considered whether humans have an innate moral sense or moral instinct and concluded that they do not. He wrote "If we be prompted by nature to the approbation of particular actions, we must have received also from nature a distinct conception of the action we are thus prompted to approve; which we certainly have not. But as this argument bears alike against all instincts, and in brutes as well as in men, it will hardly, I suppose, produce conviction, though it may be difficult to find an answer" (p. 15). Morgan may have read this passage as supporting his own position that animals do not have instincts. However, elsewhere Paley certainly accepted that animals do have instincts and that they do not reason; see Paley, Natural Theology (London: R. Faulder, 1802; reprint: New York: American Tract Society, 1848) chapter 18, 199-210. 